\title{
4. Histories with traction: Macassan contact in the framework of Muslim Australian history
}

\author{
Regina Ganter
}

\section{Introduction}

Australia's pre-British contact with the Indonesian archipelago is one of the most intriguing chapters of Australian history. ${ }^{1}$ These early Indonesian visitors, long referred to in the introductory byline of standard Australian histories as 'Macassans', once came and went without a trace. But they have now become a staple part of the Australian story, no longer considered incidental and inconsequential.

The pockets of awareness of the histories of 'Afghans', 'Macassans' and 'Malays' in Australia - none of which is a strictly ethnic appellation-have been forged into a cohesive historical narrative by the 'War on Terror', which redefined all of these groups by the religion they held in common. They have now become interesting historical subjects and in the past 10 years Australia's major cultural institutions have engaged with these histories. They have now become well entrenched in the Australian historical narrative and they have become useful histories for a range of socio-political purposes in Australia. The 'Macassan' history now has political traction.

Muslim organisations in Australia have long grasped the importance of remembering the long genealogy of Muslim contact in Australia, which began with the Macassans. Many of their publications referred to the Macassan trepangers and the later Afghan cameleers as the historical anchors of their presence in Australia. Rather than emphasise conflict and disempowerment - as white-authored histories of ethnic minorities have tended to - they underlined the long and predominantly harmonious accommodations with white and black Australia. Indigenous people, too, have shown a palpable sense of engagement with their mixed histories with Asian, Pacific and Muslim people, as I discovered during my fieldwork in northern Australia between 1986 and 1996. This is particularly the case with Macassan contact history, which anthropologists and

1 Thank you to Campbell Macknight and an anonymous reviewer for incisive comments on an earlier version of this chapter. 
archaeologists had started to recover. The Macassan contact history was also used by Yolngu people as a paradigm of accommodative rather than conflictive ethnic relations.

\section{Muslims in Australian public history}

The groundwork for a reappraisal had been laid during the 1980s, a decade of historical introspection, with large and well-funded nationwide history projects leading up to the bicentennial celebrations in 1988. The history profession was determined not to write 'history as usual', but to undertake a bottom-up approach, where ordinary lives mattered and cultural diversity was celebrated. This created an impulse to write Asians back into Australian history, including a series of books and films on Afghans in Australia.

Australian institutions started to become more interested in such histories, responding to new waves of migrants and emerging signs of ethnic tension. Museum Victoria sponsored a collection of essays on Muslims in Australia in 1992, which pointed out that one-third of all Muslims in Australia were born in the country, and the Australian Government Publishing Service published a survey of Muslim settlement in Australia in 1994 (Jones 1992).

The War on Terror, declared in 2001, sparked a redesignation of ethnic groups according to religion and reignited an interest in historiographies of Muslim presence. Some Muslim organisations have drawn on their own historians to rework the history of Islam in their State. The Islamic Council for Victoria published a history of Muslims in Australia by Bilal Cleland of the Australian Federation of Islamic Councils in 2003, which forms the basis for the comprehensive historical treatment in the Islam Australia network and the Islamic Council of New South Wales (Cleland 2003). In 2007 Almir Colan premiered his documentary Muslims in Australia Since the 1600s, accompanied by a web site. Queensland has had its own Muslim Historical Society since 2008, and in May 2010 an Islamic Museum of Australia was initiated in Melbourne. This will certainly bring together what have long appeared as disparate themes in Australian historiography into a history of Muslim presence, including Macassan, Malay, Afghan and later ethnic enclaves.

The Wikipedia entry on Islam in Australia, begun in May 2005, tackles the old popular conception straight on:

Although Islam's presence in Australia is often perceived to be recent by Australian non-Muslims, adherents of Islam from what is today Indonesia had in fact been visiting the Great southern land prior to colonial era settlement of European Christians. For several centuries these Muslims 
had traded with coastal Aboriginal peoples of the north. The common misconception among Australian non-Muslims that Islam is new to Australia is due mostly to knowledge of Islam and Muslims limited only to the recent migratory waves. (Wikipedia, 'Islam in Australia')

Now part of a narrative on Muslims in Australia, as a defensive strategy against the xenophobia directed at Muslims in Australia since 2001, the Macassan contact history has moved from the margin to the core of Australian historical understanding. During Kevin Rudd's prime ministership, the Department of Foreign Affairs and Trade web site had an elegant diplomatic pointer to a shift in attitude since the demise of the Howard government, with this lead paragraph in English and Indonesian: 'Muslims in Australia have a long and varied history that is thought to pre-date European settlement. Some of Australia's earliest visitors were Muslim, from the east Indonesian archipelago. They made contact with mainland Australia as early as the 16th and 17th centuries' (DFAT n.d.).

Australia's major institutions have made reference to Muslim histories of Australia, and many of them have started to include the Macassan history in this perspective. The National Gallery of Australia's Crescent Moon exhibition in 2006 on Islamic art in Southeast Asia included the Macassan traders in northern Australia. The National Museum of Australia added the Macassan contact history to its permanent Australian Journeys exhibition in 2008 and in 2011 Museum Victoria produced the Trepang exhibition and book (Langton et al. 2011).

For the most part, these histories are potted accounts that are general enough to be uncontroversial. But the details of the story are highly contested and any agreement is hard won by specialists. Most effort has been spent on debating the question of dates, particularly the question of first contact, in order to gauge how long the Indigenous people in the Macassan contact zone were exposed to foreign cultural influences. The topic of a Muslim legacy on Indigenous cosmology has always been treated with some circumspection. First, this is because Indigenous people are protective of their intellectual property and can use the full gamut of options from non-disclosure to legal proceedings. I have myself deleted certain things from my book drafts after consulting with my informants. Second, there is a degree of uncertainty over what portion of the 'Macassans' were Muslim, and to what degree they themselves were indigenous people of the islands with pagan beliefs, customs and rituals. 


\section{Islam and Indigenous cosmology}

According to current knowledge, and following Macknight, the trepang trade to the north coast reached the Kimberley in the 1750s and Arnhem Land in 1780. It was in full swing around 1800, always just a few paces ahead of the British assault on the southern part of the continent.

Islam, having reached the Malay Archipelago remarkably early in the seventh century, progressed slowly and gradually, but gained pace in the sixteenth century, when the Portuguese competed for social dominance in the region. McIntosh notes that, like elsewhere on the globe, in the archipelago religious conversion was an important goal for Muslim traders in their commercial colonisation. The Kingdom of Gowa, with Makassar as its centre, formally embraced Islam in 1603-05, and by the end of that century there was little trace of an indigenous creed. It is assumed that the fishers who visited northern Australia in the eighteenth and nineteenth centuries were therefore predominantly Muslim (Tjandrasasmita 1978, cited by MacIntosh 1996a). The 'outward signs of conversion' were circumcision and the adoption of Arabic names such as Hussein.

As a result of this longstanding contact, Yolngu languages are tinted with Malay, Bugis and Makassarese inflections much like English is inflected with French, and in both cases this is more obvious to the non-native speaker who is familiar with the foreign language. The extent of the suffusion of Muslim elements into the traditional Yolngu culture of northeast Arnhem Land has been subject to some speculation. Even before the British colonisation of the Australian continent, the British East India Company hydrographer Alexander Dalrymple reported in 1762 that the Aborigines of New Holland visited by the trepang fleets were 'Mahometans'. Macknight thinks this impression may have arisen from the practice of circumcision among Yolngu and it was evidently an overstatement. But there is a remnant vocabulary in Yolngu rituals that is derived from Muslim prayer, and it has long been observed that their most important religious ceremonies are strongly inflected with Macassan influences. 'Macassan' - or rather a mixture of the trade languages of Malay, Bugis and Makassarese - was once a lingua franca to interact with outsiders, and continues to be used by ceremonial leaders, much like the Catholic Church held on to Latin longer than other learned circles, and a familiarity with that foreign language continues to be a mark of prestige and learning. With the arrival of Christian missions in the mid-twentieth century the Muslim allusions in Yolngu mythology were downplayed and often went unexplained. This may be why the Macassan connections appear so difficult to tease out of recorded statements. Ian McIntosh (2009) argues that a strategic decision was taken by Yolngu elders 
under pressure of rapid changes in the mid century to downplay some aspects of their cosmology (turning them inside) and allow others to be publicised (turning them outside). We appear to be left with shreds of evidence.

In the Manikay song-cycle genre of Yolngu songs, ethnomusicologist Peter Toner detects traces of classical Arabic religious music (Toner 2000). Yolngu singers improvise with sacred texts, and icons of Macassan contact like ships, anchors, swords and flags are among the important symbols. According to descriptions by Yolngu elders, prayer-men (or imam) accompanied the Macassan trepang fleets. These were the ceremonial leaders, a role referred to as 'sick-man' (buwagerul) in the Yolngumatha language of northeast Arnhem Land. One of them is still remembered by name as Deingaru, also known as Baleidjaka. ${ }^{2}$ David Burrumarra remembered in the 1980s with amazing detail how an imam or 'sickman' would climb to the top of the mast to chant when the fleet departed, and pray at sunset, resounding an 'ama!' towards the setting sun, then bow his head to the ground and exclaim 'walata'walata!' (McIntosh 1996a, p. 7).

The same term, 'Walitha'walitha', ${ }^{3}$ is also the name of the creation spirit, sometimes translated as 'the most high God' or Allah. We need to keep in mind that the people who recorded these stories did not speak Arabic or Malay or Makassarese, and did not always distinguish between these different languages embedded in accounts rendered in Yolngumatha or Kriol, so we are faced with phonetic approximations. The Walitha'walitha creation spirit belongs to the Wuramu song cycle of northeast Arnhem Land, which is a mourning ritual that Yolngu say they 'share with Macassans'. In this ceremony the words 'Ooooa-hal-la' and 'A-ha-la' are exclaimed, and it contains appeals to the god in the heavens. These were transcribed as: 'si-li-la-mo-ha-mo, ha-mo-sil-li-li' and 'rabin-a-la la-ha-ma-ha-ma', and ending with 'Se-ri ma-kas-si' (McIntosh 1996b; Macknight 2011). The similar-sounding 'terima kasih' means 'thank you' in Malay (and Indonesian).

The carved Wuramu figures usually depict a figure with a songkok (Muslim cap). Sometimes this cap is quite elongated, showing an earlier fashion. Historically this song cycle derives from an incident of a ritual performed by Macassans at Cape Wilberforce, reportedly for the burial of a group of Aborigines; however, its meaning has been reworked to blend Yolngu beliefs and Macassan rituals, and there are multiple layers of meaning attached to the Wuramu figure, so that each explanation is only partial. The ritual extends over several days, containing imagery reminiscent of exchanges with Macassans, such as a flag dance, a knife dance, a boxing dance, a smoking dance, an alcohol dance (where

2 It is a feature of many contact stories that the protagonist has both a Macassan and a Yolngu name, expressing relatedness and family connections to both sides.

3 I take 'Walitha'walitha' to be the same as 'walata'walata' in the line above, a difference that may arise from different phonetic conventions, just like the difference between Arrernte and Arunda, for example. 
dancers feigning to be intoxicated try to wrestle and dance at the same time), a lunggurrma dance (referring to the northeast monsoon wind associated with the arrival of the trepang fleets) as well as storytelling elements brought back from Yolngu who had spent time in Makassar, such as reminiscences of rice paddies, shipbuilding and lily ponds (McIntosh 1996b).

McIntosh emphasises that Yolngu never embraced Islam as a faith; rather, they incorporated elements of what they observed from their Indonesian visitors into their own cosmology. It is tempting, however, to speculate where this development might have led theologically had not the British begun to conquer the same territory at the turn of the nineteenth century, ousted the Muslim visitors and introduced Christian missions. Evicting the Macassan trepang fleets in 1906 was a last-ditch attempt to claim a thriving trading opportunity with China for the European colonisers. It was just a few years before the Commonwealth took over the Northern Territory in 1911, after the anticipation of riches in the untapped north had dissipated into a string of disappointments. The competing claims are reflected in a duality of names for many sites: Ashmore Reef is known by Indonesians as Pulau Pasir, likewise Scott Reef is Pulau Datu and Cartier Reef is Pulau Baru. In the Yolngu territories, apart from Indigenous names for places, there are Lembana Panrea for Melville Bay, Tarrusanga for Bowen Strait, Lemba Moutiaria for Port Essington and Lemba Binangaja for Trepang Bay. In some cases Yolngu even accepted Macassan terms for sites, such as Gunyangarra for Ski Beach at Yirrkala, which derives from Kodingareng Lompo, the name of an island in the Spermonde Archipelago, offshore from Makassar (see Clark, this volume; Ganter 2006; Macknight 1976b).

At the turn of the twentieth century there were Yolngu people who were circumcised, polygamous, well-travelled, enmeshed in transnational trade and family relationships, who spoke using vocabulary used by the Macassans and carried Macassan names. The Yolngu had made room for Muslim ceremony in their own rituals and appear to have been on a path of natural, unforced conversion when the Christian missionaries arrived.

Since the mid 1980s, just as the last eyewitnesses were passing away, the Macassan contact stories have undergone a revival and mutual visits have recommenced. This is precisely what happened 10 years later in white Australia with the revival of the Anzac legend, which focused on the story of the disastrous Australian landing at Gallipoli, Turkey, during World War I. With the passing of the World War I veterans, the Anzac 'legend' transformed for the majority of Australians from being a story owned and enacted by old men to being a story about real places ready to be explored by a younger generation who were starting to travel overseas. With the participation of Turkish officials, Australian ceremonies were being held on Turkish soil. 


\section{Muslim history as empowerment}

A revival of the Yolngu-Macassan contact history emerged in the 1980s in the wake of the 1976 Northern Territory Land Rights Act, which led the way in Australia to a national recognition of Indigenous rights over country and the statutory recognition of land councils. A strong sense of ownership emerged among Indigenous people in the Northern Territory, over their country, over their languages, over their histories. The Milingimbi Literature Centre recorded and published stories in Yolngumatha, among them stories of Macassan contact (Djawawungu 1979; Bopaniwungu 1988). In 1985 the first Barunga festival took place, facilitating an exchange of traditions and stories, art and culture, and in 1986 the highly respected Yolngu elder Wandjuk Marika recorded the story of Djaladjari, a Yolngu man who had been to Makassar several times, for a group of young Yolngu students at Batchelor College planning to visit Makassar.

The last phase of Macassan-Yolngu contact was still accessible to oral history when Campbell Macknight and Peter Spillett were conducting fieldwork in the 1960s and 1970s. Macknight, working under the supervision of the iconic Professor John Mulvaney, began to rediscover some of the names of Indonesian captains in the customs records, and matched them with names remembered in various stories told by Yolngu. He made contact with the family of Husein Daeng Rangka in Makassar, who was the last of the captains who came to Australia and whose career is practically reflected in the Australian customs records. A 1981 issue of Aboriginal History contained two important essays on the Macassan influence in the Yolngu languages, reflecting linguistic work then being undertaken (Urry and Walsh 1981; Walker and Zorc 1981).

Husein Daeng Rangka and members of his family appear in a range of Yolngu stories, though with different spellings, sometimes difficult to recognise. The Arabic name Husein becomes 'Using' or 'Oesing' in Indonesian. The 'Daeng' in his name devolves from an old honorific title from the ancient Kingdom of Gowa on Sulawesi and is widespread in Makassar (Macknight 1976b). It was also devolved to some of their Aboriginal relatives and trading partners in Australia where it appears as the prefix 'Dayn' in Yolngu names. Husein Daeng Rangka had at least two Aboriginal wives (Macknight 1976a). He is also reported to have abducted a wife of Ganimbirrngu, who was the leader at Melville Bay (Lembana Panrea in Yolngu territory). The Macassans referred to the latter as the 'raja of Melville Bay', and Husein Daeng Rangka bestowed on him the name of Dayngmangu (Macknight 1976b, p. 84). This was the father of David Burrumarra, informant for most researchers conducting fieldwork there until the 1980s. The family connections are closely woven. 
Peter Spillett from the Northern Territory Museum instigated a bicentennial project to reconstruct a traditionally crafted perahu padewakang, the type of boat used in the trepang trade, to sail once more from Makassar to the Top End of Australia, known by the Macassans as Marege'. He accompanied the Batchelor College students on a visit to Makassar in 1986, at which time it was called Ujung Pandang. They were amazed at the similarity in language, expressions and names they encountered. They felt as if old legends were coming alive in front of them, to see the characteristic sails, men wearing the songkok caps, also known as peci, as well as all the iconography from the paintings at home. Based on discussions with several of these students, it was evident that they felt great amazement that the Mangathara (Yolngumatha for Macassans) of the old stories really existed (see also Spillett 1987). It was only a few years since the last of the known travellers to Australia had died, in 1978, Mangnellai Daeng Maro. As a boy of about ten, he had accompanied his father, Husein Daeng Rangka, to Australia.

The Hati Marege bicentennial project (see chapters by Macknight and McIntosh, this volume) caused a flurry of negative media reportage because the Northern Land Council had objected to the flying of the bicentennial flag on the prau, arguing that this history had nothing whatsoever to do with the bicentennial or the arrival of the British anywhere in Australia. The Indonesian and Australian diplomats involved were faced with the possibility of a hostile reception or a cancelled event. It became a tussle about who owns this history. The Hati Marege sailed into Yirrkala precisely 200 years after the First Fleet reached Botany Bay (16 January 1988), captained by Mansjur Muhayang, a great-grandson of Husein Daeng Rangka. He handed over a bag of rice like in olden times, and was greeted by Matjuwi Burrawanga from Galiwin'ku at Elcho Island as a family member. This bicentennial project was understood as a family reunion, and was surely the single most successful bicentennial project. With it, the Yolngu people broke the isolation that had severed them from friends and relations in 1906.

This project and the personal encounters it entailed brought about an immense reinvigoration of interest in the Macassan connection among Yolngu and neighbouring Aboriginal people and set off a series of mutual visits. A Maningrida dance troupe led by artist John Bulunbulun took the Marayarr Murrukundja - a ceremony of diplomacy lasting three nights - to Sulawesi in 1993, and with this the Indonesian village news-trucks announced with blaring loudspeakers the arrival of the 'orang aborijin dari Australia utara' (Aborigines from northern Australia) (Garde 1993). On the Indonesian side there was also much amazement at the rekindling of contact. Peter Spillett, the organiser of the bicentennial project, was given the honorific name Daeng Makulle ('Mister Capability', according to Jukes 2005, p. 278). Bulunbulun spotted an old ceramic storage pot in one of the shops exactly the shape that he had always 
included in his paintings, but he had never actually seen one. He brought it home and it became one of the first items in the Djomi museum, opened in 1996 at Maningrida, which celebrates the Macassan-Yolngu connection.

The next big collaborative project was a trepang opera scripted by theatre director Andrish Saint-Clare. In 1994 he showed films of Yolngu dances in Makassar to arouse interest, and in 1996 he brought Mansjur Muhayang (referred to as Yotjing, or Otjing, as the descendant of Husein Daeng Rangka) to Elcho Island, to perform in an opera, The Trepang Project (see Blair and Hall, this volume). The following year the opera was staged in Makassar, on the foundation day of the city of Makassar (Hari Jadi Gowa) celebrations in front of a 9000-strong audience. By then, it was by a performance team consisting of six actors and musicians from Sulawesi and 10 artists from Galiwin'ku, performing 'the story of Matjuwi and Otjing who are brothers through the marriage of their grandparents'. Two years later the opera was performed at the Festival of Darwin (16-19 September 1999), and the Australian Broadcasting Corporation $(A B C)$ recorded it for video release in 2000. For the Centenary of Federation, the opera came to Federation Square in Melbourne in 2001. From the margins of history, it was moving to the central celebrations of the nation.

At the opening of the 2000 Sydney Olympics, too, the long history of Macassan contact was mentioned, by Ernie Dingo, though he claimed a wildly exaggerated history for it, perhaps following the lyrics of the Sunrize Band from Maningrida whose 1993 title Lembana Mani Mani suggests a 20 000-year history of contact. The Wirrnga band from Milingimbi produced My Sweet Takirrina in commemoration of the bicentennial project in 1990, and in 1998 the Yothu Yindi Foundation commenced the Garma Festival at Gulkula in east Arnhem Land, at which the Macassan history has always been represented. Yothu Yindi released their Garma album in 2000, containing a song with the title 'Macassan Crew'.

In dance, song and also in paintings, the Macassan history underwent a revival. In 1993 Bulunbulun was starting to collaborate with painter Zhou Xiaoping from Hebei, China, who had become artist-in-residence at Maningrida. Their collaboration was to result eventually in a Chinese book by Xiaoping and exhibitions in Beijing and Melbourne in 2011 (see Clark and May, this volume; Xiaoping 2006, some of which is republished in Langton et al. 2011). Bulunbulun's series of 25 paintings reflecting Macassan stories in the Yirrtitja song cycle, one of them in Darwin Airport, received national acclaim. He revealed the clan totem Lunggurrma (north wind) as a symbol of the seasonal arrival of the Macassans.

Yolngumatha does not make a distinction between British and Indonesian foreigners, referring to both as 'balanda' (derived from Malay/Indonesian words referring to the Netherlands or the Dutch, 'Belanda' or 'orang Belanda' 
respectively). But Yolngu do distinguish between the effects of Macassan contact and British colonisation. There are ample indications of violent conflict in their myths and in the historical record, but the Macassan contact is now so long ago that there are no eyewitnesses left and it has become remembered as a period of trade and exchange without compulsion, in contradistinction with the British colonisation. The telling of the Macassan stories has become an act of resistance. It refuses to allow a government decision to sever the link to Makassar. It also asserts that Yolngu have long engaged in contact with outsiders without surrender or colonisation. In 1998 a group of Croker Island people lent on this history to support a sea claim, arguing that the Macassans had obtained prior permission for using the seas controlled by Yolngu, and that they negotiated payments-in-kind. The judge rejected the claim (Russell 2004).

Despite the negative legal decision outlined above, the Australian Government has also gained some mileage in the mixed histories of the north. In 2008 the Department of Foreign Affairs launched its IN2OZ program of cultural exchange with Indonesia, and sent among its cultural ambassadors to Indonesia two Indigenous women who have Asian ancestry: Australian Idol star Jessica Mauboy, Darwin daughter of an Indigenous mother and a Timorese father, and novelist Alexis Wright, with Mornington Island/Gulf of Carpentaria family roots. Such figures personify the poly-ethnic past in Australia where Asians and Muslims are not 'outsiders'.

Finally, the Australian historical imagination has begun to embrace the idea that Australian history starts well before the arrival of the British, and the Macassan contact chapter is being written into the script because it is no longer seen as inconsequential. It is a history that has traction for a range of purposes: Yolngu people draw cultural pride from their transnational history, Aboriginal organisations deploy their history of trade in mounting legal arguments about native title, Muslim organisations point to their long anchor in the historical presence in Australia, and diplomatic circles support cultural exchange and the celebration of shared histories with Australia for geo-strategic reasons in what the Australian Government now calls the 'Asian century'. Schoolteachers have started to fit the Macassan story into the national history curriculum, showing a more transnational Australia interacting with its nearest neighbours. There is much that remains to be discovered about this story, and our challenge is to get the details right without becoming too doctrinaire for a wide audience. 
4. Histories with traction: Macassan contact in the framework of Muslim Australian history

\section{References}

Bopaniwungu (1988) Daewu Dhuwal Gpiyawuywainguwuy. Ga Mangatharrawainguwuy, Roneo, Milingimbi Literature Centre, Milingimbi, NT.

Cleland, B. (2003) The Muslims in Australia: A brief history, Melbourne: Islamic Council for Victoria, <www.islam.iinet.net.au/channel/near_north.html> [viewed November 2011].

Colan, A. (2007) Muslims in Australia Since the 1600s, (VHS and About Documentary Film), <http://muslimsinaustralia.com/about/> [accessed November 2011].

Denoon, D., P. Mein-Smith with M. Wyndham (2000) A History of Australia, New Zealand and the Pacific, Oxford and Malden, Mass.: Blackwell.

Department of Foreign Affairs and Trade (DFAT) (n.d.) Muslims in Australia, Canberra: Department of Foreign Affairs and Trade, <http://www.dfat.gov. au/facts/muslims_in_australia_in.html > [accessed October 2011].

Djawawungu (1979) Dhae-Dhuditjpuy Mangatharra (The last visit of the Macassans), Roneo, Milingimbi Literature Centre, Milingimbi, NT.

Dunn, K. M., A. Kamp, W. S. Shaw, J. Forrest and Y. Paradies (2010) 'Indigenous Australians' attitudes towards multiculturalism, cultural diversity, "race" and racism', Journal of Australian Indigenous Issues, 13 (4), pp. 31-40.

Ganter, R. (2006) Mixed Relations: Asian/Aboriginal contact in north Australia, Perth: University of Western Australia Press.

Garde, M. (1993) The Marayarr Murrkundja Ceremony Goes to Makassar, Maningrida, NT: Bawinanga Aboriginal Corporation.

Jones, M. (ed.) (1992) An Australian Pilgrimage: Muslims in Australia from the seventeenth century to the present, Melbourne: Victoria Press in association with Museum of Victoria.

Jukes, A. (2005) 'Makassar', in K. Alexander Adelaar and N. Himmelmann (eds), The Austronesian Languages of Asia and Madagaskar, New York: Routledge, pp. 647-82.

Langton, M., A. Duschatzky and S. Holt (eds) (2011) Trepang: China and the story of Macassan-Aboriginal trade, Melbourne: Centre for Cultural Materials Conservation, Museum Victoria. 
McIntosh, I. (1996a) Can we be equal in your eyes? A perspective on reconciliation from north-east Arnhem Land, Unpublished PhD thesis, Northern Territory University, Darwin.

McIntosh, I. (1996b) 'Islam and Australia's Aborigines? A perspective from north-east Arnhem Land', Journal of Religious History, 20 (1) (June), pp. 53-77.

McIntosh, I. (2009) 'Missing the revolution! Negotiating disclosure on the preMacassans (Bayini) in north-east Arnhem Land', in M. Thomas and M. Neale (eds), Exploring the Legacy of the 1948 Arnhem Land Expedition, Canberra: ANU E Press.

Macknight, C. C. (1976a) 'Husein Dg. Rangka', Australian Dictionary of Biography. Volume 6, Carlton, Vic.: Melbourne University Press.

Macknight, C. C. (1976b) Voyage to Marege': Macassan trepangers in northern Australia, Carlton, Vic.: Melbourne University Press.

Macknight, C. C. (2011) 'The view from Marege': Australian knowledge of Makassar and the impact of the trepang industry across two centuries', Aboriginal History, 35, pp. 136-57.

Onnudottir, H., A. Possamai and B. S. Turner (2010) 'Islam: a new religious vehicle for Aboriginal self-empowerment in Australia?' International Journal for the Study of NewReligions, 1 (1), pp. 49-74.

Russell, D. (2004) 'Aboriginal-Makassan interactions in the eighteenth and nineteenth centuries in northern Australia and contemporary sea rights claims', Australian Aboriginal Studies, (1), pp. 3-17.

Spillett, P. (Daeng Makulle) (1987) Gotong Royong: Hubungan MakassarMarege', Paper presented to the Second International Convention of the Indonesian Educational and Cultural Institute, Ujung Pandang, Indonesia, July.

Tjandrasasmita, U. (1978) 'The introduction of Islam and the growth of Moslem coastal cities in the Indonesian archipelago', in H. Soebadio and C. A. du Marchie (eds), Dynamics of Indonesian History, Amsterdam.

Toner, P. (2000) 'Ideology, influence and innovation: the impact of Macassan contact on Yolngu music', Perfect Beat: The Pacific Journal of Research into Contemporary Music and Popular Culture, 5 (1), pp. 22, 33-4.

Urry, J. and M. Walsh (1981) "The lost "Macassar language" of northern Australia', Aboriginal History, 5 (2), pp. 91-108. 
4. Histories with traction: Macassan contact in the framework of Muslim Australian history

Walker, A. and R. D. Zorc (1981) 'Austronesian loanwords in Yolngu-Matha of northeast Arnhem Land', Aboriginal History, 5 (2), pp. 107-34.

Xiaoping, Z. (2006) A Dream of Aboriginal Australia [in Chinese, not translated]. 